\title{
A Rare Presentation to the Emergency Department with Confusion: Cerebral Malaria
}

\author{
Bilinç Bulanıklığı ile Nadir Bir Başvuru; Serebral Sıtma
}

Gökçe Akgül Karadana', Özlem Dikme², Selman Yeniocak', Hakan Topaçoğlu²

'Department of Emergency Medicine, Haseki Training and Research Hospital, İstanbul, Turkey 2Department of Emergency Medicine, İstanbul Training and Research Hospital, İstanbul, Turkey

\section{ABSTRACT}

Introduction: In the case of patients presenting to the emergency department with confusion, many diseases should be considered in the differential diagnosis. Cerebral malaria is a serious complication of malaria presenting with somnolence, coma, delirium, and seizures and has a mortality rate of $20 \%$.

Case Report: In this report, we present the case of a patient who was brought by ambulance to the emergency department with sudden onset of confusion, which was eventually diagnosed as cerebral malaria.

Conclusion: In patients presenting with confusion, obtaining detailed and repetitive history can be life-saving.

Keywords: Consciousness, fever, malaria

Received: 21.08.2014 Accepted: 16.12.2014

\section{ÖZET}

Giriş: Acil servise bilinç bulanıkığı ile başvuran hastalarda ayırıcı tanıda birçok hastalık gözden geçirilmelidir. Bir sıtma komplikasyonu olan serebral sıtma somnolans, koma, deliryum ve nöbetle seyreden, mortalitesi \%20'leri bulan ciddi klinik bir tablodur

Olgu Sunumu: Acil servise ambulansla ani başlayan bilinç bulanıklığı ile getirilen ve serebral sıtma tanısı alan bir olgu sunulmuştur.

Sonuç: Bilinç bulanıkığı ile başvuran hastalarda ayrıntılı ve tekrarlayan hikaye almak hayat kurtarıcı olabilmektedir.

\section{Giriş}

Acil servise bilinçte değişiklik şikâyeti ile başvuran hastalarda uygun sistematik bir yaklaşım hayat kurtarıcı olabileceğinden çok önemlidir. Bilinç bozukluğu hafif uyku halinden komaya kadar uzanan geniş bir spektrumda kendini göstermektedir. Ayırıcı tanıda metabolik ve sistemik bozukluklardan yapısal lezyonlara kadar birçok hastalık gözden geçirilmelidir. Genellikle periyodik üşüme, titreme ve ateş ataklarına yol açan, ciddi olgularda özellikle anemi, solunum yetmezliği ve koma ile seyredebilen sıtma bilinç değişikliği nedenlerinden biridir. Bu olgu sunumunda acil servise ani gelişen bilinç bulanıklığı ile getirilen ve serebral sıtma tanısıyla yoğun bakıma yatırılan bir olgu sunulmuştur.

\section{Olgu Sunumu}

41 yaşında erkek hasta sabah başlayan ve giderek artış gösteren bilinç bulanıklığı nedeniyle ambulansla acil servise getirildi. Hastanın yanında gelen arkadaşlarından ve ambulans ekibinden hastanın öyküsü ve özgeçmişi ile ilgili yeterli bilgi alınamadı. Ambulansla transferi esnasında nöbet geçirdiği belirtilen hastanın gelişte bilinci kapalı, koopere ve oryante değildi. Hastanın geliş vital bulguları Kan basıncı 110/70 mmHg, Vücut ısısı 37,1 C, Nabız 100/dk, Solunum sayısı 16/dk olarak saptandı. Kan şekeri 107 mg/dL olarak ölçülen hastanın geliş EKG'sinde patoloji saptanmadı. Nörolojik muayenesinde glasgow koma skalası (GKS) $E_{1} M_{4} V_{2}$, fokal nörolojik defisit ve ense sertliği saptanmadı. Hastaya maske ile 2-4 It/dk'dan oksijen başlandı. Damar yolu açılarak laboratuvar tetkikleri için kan alındı ve ardından sıvı tedavisine başlandı. Alınan kan örneklerinde Hb: 13,9 g/dL, RBC: 4,14 M/uL,

\section{Address for Correspondence/Yazışma Adresi:}

Gökçe Akgül Karadana, Department of Emergency Medicine, Haseki Training and Research Hospital, İstanbul, Turkey.

Phone: +90 5332861488 E-mail: drgokceakgul@gmail.com 
WBC: 9,7 M/uL, Plt: 18 M/uL, INR: 1,01, APTT: 25,06 sn, CRP: 266 mg/L, Laktat: 6,1 kan biyokimya analizinde, kan elektrolit düzeyleri, karaciğer ve böbrek fonksiyon testleri ve kardiyak belirteçleri normal idi (Tablo 1). Bilgisayarlı beyin tomografisi, kontrastlı ve difüzyon beyin manyetik rezonans görüntülemesinde anormallik saptanmadı. İzleminde miyoklonik kasılmaları olan hastaya 500 mg intravenöz (iv) fenitoin yükleme yapıldı. Bilinç bulanıkıı̆ı devam eden hastanın acil serviste izlemi esnasında vücut IsISı $38,6^{\circ} \mathrm{C}$ 'ye yükseldi. Ateş etiyolojisine yönelik çekilen akciğer grafisi normal olarak raporlanan hastanın idrar tetkikinde enfeksiyon bulgusuna rastlanmadı. Hastanın kan kültürleri alınıp sıvı resüsitasyonuna başlandı. Lomber ponksiyon yapılması planlandı ancak yapılmadan önce hastanın acil servise sonradan gelen eşinden alınan öyküye göre 10 gün öncesinde Afrika seyahatinin olduğu ve önerilmesine rağmen herhangi bir profilaktik ilaç kullanmadığı öğrenildi. Bu bulgular eşliğinde istenen Enfeksiyon Hastalıkları konsültasyonu sonrası hastaya yapılan periferik kan ince ve kalın yaymasında Plasmodium falciparum tipi parazit tespit edildi. Hasta serebral sıtma tanısı konularak yoğun bakım ünitesine yatırıldı. Yoğun bakım ünitesinde entübe edilen hastaya sıtma savaş ekibi tarafından getirilen Artesunate 0., 12., 24. saatte 180 mg iv. sonrasında günde 1*180 mg idame olacak şekilde başlandı. Miyoklonik kasıllmaları devam etmesi üzerine hastaya pentotal infüzyonu uygulandı. Yoğun bakım yatışından 11 gün sonra bilinç ve genel durumunda düzelme sağlanan hasta Enfeksiyon hastalıkları kliniğine alınarak oradan 3 gün sonrasında taburcu edildi.

\section{Tartışma}

Bilinç bozukluğu acil servise sık başvuru nedenlerinden biridir. Acil servise bilinç bozukluğu ile başvuran hastalarda öncelik hasta stabilizasyonunu sağlamak olmalıdır. Bu amaçla hastanın havayolu, solunum, dolaşım (ABC) basamakları hızla gözden geçirilmelidir (1). Hipoglisemi, hipoksemi ve şok gibi hayatı tehdit eden durumlar öncelikle ele alınmalı, vital bulguları, oksijen saturasyonu, kan şekeri öl-

\section{Tablo 1. Laboratuvar Sonuçları}

\begin{tabular}{ll} 
Karaciğer Fonksiyon Testleri & ALT: $53 \mathrm{U} / \mathrm{L}$ \\
& AST: $50 \mathrm{U} / \mathrm{L}$ \\
& Total/Direkt bilirubin: 5,28/1,55 mg/dL \\
\hline Böbrek Fonksiyon Testleri & BUN: $36 \mathrm{mg} / \mathrm{dL}$ \\
& Kreatinin: 0,63 mg/DL \\
& Na: $132 \mathrm{mmol} / \mathrm{L}$ \\
& K: $4,11 \mathrm{mmol} / \mathrm{L}$ \\
& Cl: $96 \mathrm{mmol} / \mathrm{L}$ \\
& Ca: $8,92 \mathrm{mg} / \mathrm{DL}$ \\
& CK:65 U/L \\
& CK-MB: $0,9 \mathrm{ng} / \mathrm{mL}$ \\
Kardiyak Belirteçler & Troponin I: $0,0046 \mathrm{ng} / \mathrm{mL}$ \\
& LDH: $354 \mathrm{U} / \mathrm{L}$
\end{tabular}

ALT: alanin aminotransferaz; AST: aspartat aminotransferaz; BUN: kan üre nitrojen; Na: sodyum; K: potasyum; Cl: Klor; Ca: kalsiyum; CK: kreatin kinaz; CKMB: kreatin kinaz myokard band; LDH: laktat dehidrojenaz çümü bilinç bozukluğu ile gelen her hastada bakılmalıdır. Gerekliyse iv. veya oral glukoz, oksijen ve sıvı resüsitasyonu uygulanmalıdır. Bilinç bozukluğu ile gelen hastalarda dikkatli bir hikâye ve fizik muayene şarttır. Tanıya ulaşmada yatak başı yaklaşımlar ve bunlara hastanın yanıtı (glukoz, naloksan vs.) yanında laboratuvar testleri ve görüntüleme yöntemleri gerekebilmektedir (2). Bilinç bulanıklığı etiyolojisinde metabolik ve sistemik hastalıklar \%85, yapısal lezyonlar (travma, serebral hastalıklar, tümör, enfeksiyon vs.) \%15 rol almaktadır (1).

Ayırıcı tanıda ayrıntılı alınan öykü hayat kurtarıcı olabilmektedir. Özellikle seyahat öyküsü olan hastalarda ateşle birlikte bilinç bulanıklığı olduğunda sıtma akılda tutulması gereken etkenlerden biridir. Sıtma özellikle tropikal ve subtropikal bölgelere seyahat öyküsü olanlarda görülen ve yüksek oranda ölümcül seyreden protozoal bir hastalıktır (3). Her yıl 500 milyon üzerinde kiş̧ide sıtma görülmekte ve buna bağlı 1 milyonun üzerinde insan ölmektedir $(4,5)$. Özellikle Plasmodium Falciparum türüne bağlı olan formu immün olmayan kişide ciddi bir medikal acildir ve tedavi edilmezse mortalitesi \%50'lere kadar ulaşabilmektedir. Açıklanamayan febril hastalıklarda tropikal bölgelere seyahat öyküsü varsa ayırıcı tanıda sıtma mutlaka düşünülmelidir.

Bulunduğu bölgeye göre Plasmodium ile enfekte kişilerde beş formdan biri görülmektedir; P. Vivax, P. Ovale, P. Malarya, P. Falciparum ve yeni bir tür olan P. Knowlesi. Örneğin P. Vivax Hint Yarımadası ve Orta Amerika'da, P. Falciparum Afrika, Haiti ve Yeni Gine'de P. Knowlesi Malezya, Myanmar (Burma), Tayland, Filipinler ve Singapur'da daha sıklıkla görülmektedir (6).

Organizma primer olarak anofel cinsi dişi sivrisinekler tarafından ısırılma ile taşınmaktadır. Bu vektör sıklıkla tropikal ve subtropikal bölgelerde deniz seviyesinden 2500 metre yüksekte görülmektedir.

Sıtmanın klinik bulguları periyodik ateş, halsizlik, miyalji, baş ağrısı, titreme şeklinde görülmektedir. Ilk klinik bulguları viral hastalık bulgularıyla karışabilmektedir. Bulguların benzerliği nedeniyle ayırıcı tanıda bakteriyel sepsis düşünülmelidir.

Özellikle ajan P. Falciparum olduğunda ve tedavi edilmemiş olgularda malarya komplikasyonları görülebilmektedir. Serebral sıtma, somnolans, koma, deliryum ve nöbetle seyreden ve mortalitesi \%20 'leri bulan bir malarya komplikasyonudur. Ayırıcı tanı amacıyla bakteriyel menenjit ve ensefalit açısından lomber ponksiyon endikedir. Serebral sıvı, serebral malaryada sıklıkla normal olmakla birlikte, hafif yükselmiş açılış basıncı, protein konsantrasyonu veya orta düzeyde pleositoz görülebilmektedir.

Yüksek oranda klinik şüphe ve kalın ve ince kan yaymada parazitlerin görülmesi ile tanı konulur. Tedavi kararı hastalığın ciddiyetine, ajana, klorokin-dirençli P. Falciparum olup olmamasına göre belirlenir $(5,7)$. Bizim olgumuzda klorokin-dirençli P. Falciparum düşünüldüğünden Artesunate başlanmıştır (2.4 mg/kg iv 0., 12., 24. saatte ve 2.4 mg/kg/ gün 3 gün boyunca).

Sıtmadan kişisel koruyucu önlemler ve uygun kemoprofilaksi ile büyük oranda korunmak mümkündür. Seyahat eden kişilerin sıklıkla 
sivrisineğe karşı önlem almadığı ve önerilen antimalaryal ilaçları kullanmadığı görülmüştür $(8,9)$. Uygun kemoprofilaksi almamak fatal enfeksiyon için önemli bir risk faktörüdür (10).

Olgumuzda yaklaşık 10 gün öncesinde Afrika'ya iş seyahati öyküsü olduğu ve önerilen medikasyonları kullanmadığı tekrarlayan hikâye ile tespit edilmiş, acil servise sonradan ulaşabilen eşinden öğrenilmiştir.

\section{Sonuç}

Bilinç bulanıklığı ile acil servise başvuran hastalarda öykünün ayrıntılı ve gerekirse tekrar tekrar alınması hayat kurtarıcı olabilmektedir.

Informed Consent: Written informed consent was obtained from patient's relative who participated in this case.

Peer-review: Externally peer-reviewed.

Author Contributions: Concept - G.A.K.; Design - G.A.K., Ö. D.; Supervision - H. T.; Materials - G.A.K., S. Y.; Data Collection and/or Processing - G.A.K., S. Y.; Analysis and/or Interpretation - G.A.K.; Literature Review - G.A.K.; Writer G.A.K.; Critical Review - H. T., Ö. D.

Conflict of Interest: The authors declared no conflict of interest.

Financial Disclosure: The authors declared that this study has received no financial support.

Hasta Onamı: Yazılı hasta onamı bu olguya katılan hastanın yakınından alınmıştır.

Hakem değerlendirmesi: Dış bağımsız.

Yazar Katkıları: Fikir - G.A.K.; Tasarım - G.A.K., Ö. D.; Denetleme - H. T.; Malzemeler - G.A.K., S. Y.; Veri toplanması ve/veya işlemesi - G.A.K., S. Y.; Analiz ve/ veya yorum - G.A.K.; Literatür taraması - G.A.K.; Yazıyı yazan - G.A.K.; Eleştirel Inceleme - H.T., Ö. D.

Çıkar Çatışması: Yazarlar çıkar çatışması bildirmemişlerdir.

Finansal Destek: Yazarlar bu çalışma için finansal destek almadıklarını beyan etmişlerdir.

\section{Kaynaklar}

1. Cooke JL, Barsan WG. Altered Mental Status and Coma. In: Barton ED, Collings JL, DeBlieux PM, Gisondi MA, Nadel ES, Editors. James G. Adams. Emergency Medicine. Canada: Saunders Elsevier: 2008: p. 101-5.

2. Huff JS. Confusion. In: Marx J, Hockberger R,Walls R. Editors. Rosen's Emergency Medicine 7th Ed. Philadelphia: Mosby Elsevier; 2010: p. 1056-62.

3. Szela JL, Tayali JY, Band JD. Malaria. In:Tintinalli JE, Stapczynski JS, Ma OJ, Cline DM, Cydulka R, Meckler GD Editors. Tintinalli's Emergency Medicine, 7th Ed. A Comprehensive Study Guide. United States: McGraw Hill Companies: 2011: p.1056-62.

4. Greenwood BM, Bojang K, Whitty CJ, Targett GA. Malaria. Lancet 2005; 365: 1487-98. [CrossRef]

5. Greenwood BM, Fidock DA, Kyle DE. Malaria: progress, perils, and prospects for eradication. J Clin Invest 2008; 118: 1266-76. [CrossRef]

6. Cox-Singh J, Davis TM, Lee KS. Plasmodium knowlesi malaria in humans is widely distributed and potentially life threatening. Clin Infect Dis 2008: 46: 165-71. [CrossRef]

7. World Health Organization (WHO): International Travel and Health, 2009. Geneva 8. Available at: http://whqlibdoc.who.int/publications/2009/9789241580427_eng.pdf. [CrossRef]

8. Dorsey G, Ghandhi M, Oxygi JH. Difficulties in the prevention, diagnosis and treatment of imported malaria. Arch Intern Med 2000; 160: 2505-10. [CrossRef]

9. Freedman D.O, Malaria prevention in short term travelers. N Engl J Med 2008; 359: 603-12. [CrossRef]

10. Centers for Disease Control and Prevention: Malaria deaths following inappropriate malaria chemoprophylaxis_United States. MMWR Morb Mortal Wkly Rep 2001; 50: 597. http://www.ncbi.nlm.nih.gov/pubmed/1147652. 